\title{
Profiling of antioxidant enzymes in cat fish (Clarias batrachus) exposed to phenolic compounds
}

\author{
AMIT ALEXANDER CHARAN ${ }^{1}$, ARADHANA IRENE CHARAN ${ }^{1}$, OM PRAKASH VERMA ${ }^{1}$ AND \\ SYED SUAIB NAUSHAD ${ }^{2}$ \\ ${ }^{1}$ Department of Molecular and Cellular Engineering, Sam Higginbottom Institute of Agriculture, Technology and \\ Sciences, ALLAHABAD (U.P.) INDIA \\ ${ }^{2}$ Department of Biochemistry and Biochemical Engineering, Sam Higginbottom Institute of Agriculture, Technology \\ and Sciences, ALLAHABAD (U.P.) INDIA \\ Email : amit.charan@shiats.edu.in
}

Article Info :Received : 04.09.2014; Revised : 03.02.2015; Accepted : 17.02.2015

Pollution of water sources due to chemicals plays a primary role in the destruction of ecosystems but chemical analyses alone may not suffice to describe the adverse effects of the complex mixtures of chemicals present at contaminated sites. The potential utility of biomarkers for monitoring both environmental quality and the health of organisms inhabiting in the polluted ecosystems has received increasing attention during the last years. In the present investigation, the antioxidant profile of Clarias batrachus, a fresh water fish was determined by evaluation of antioxidant enzymes, SOD activity, catalase activity, glutathione peroxidase activity, glutathione-S-transferase activity, reduced glutathione, level of conjugated dienes, hydrogen peroxidase activity and malondialdehyde level. The studies showed that in fishes after exposure to phenolic compounds (treated group), there was a significant abnormal level of all the parameters as mentioned above at $\mathrm{P}<0.05$ in comparison to normal (untreated group).

Key words : Clarias batrachus, Phenolic compounds, Antioxidant profile, Antioxidant enzymes

How to cite this paper : Charan, Amit Alexander, Charan, Aradhana Irene, Verma, Om Prakash and Naushad, Syed Suaib (2015). Profiling of antioxidant enzymes in cat fish (Clarias batrachus) exposed to phenolic compounds. Asian J. Bio. Sci., 10 (1) : 6-14. 